\title{
ANALISIS PEMANFAATAN MEDIA PEMBELAJARAN YOUTUBE DALAM MENINGKATKAN PEMAHAMAN KONSEP MATEMATIKA PESERTA DIDIK
}

\author{
M. Ardiansyah ${ }^{1}$, Mohamad Lutfi Nugraha ${ }^{2}$ \\ ${ }^{1,2}$ Universitas Indraprasta PGRI \\ Jl. Raya Tengah, Kel. Gedong, Pasar Rebo, Jakarta Timur \\ ํㅡ.ardiansyah_unindra@yahoo.co.id, ${ }^{2}$ muhammadlutfinugraha@gmail.com
}

\begin{abstract}
ABSTRAK
Penelitian ini merupakan penelitian kualitatif deskriptif dengan pendekatan studi kasus melalui observasi, wawancara dan studi kepustakaan yang berlokasi di SMP Tanjung Jakarta Barat. Populasi dan sampel dalam penelitian ini adalah 2 orang pendidik matematika dan 10 siswa SMP Tanjung. Analisis data yang digunakan dalam penelitian ini adalah melalui reduksi data, penyajian data, dan verifikasi. Pengajaran matematika menggunakan media youtube sangat bermanfaat dan menarik karena fasilitas youtube banyak dan bervariasi serta dapat dipilih sesuai dengan keinginan pengguna. Bahan ajar matematika juga tersedia dan dapat diakses oleh siapa saja, di mana saja. dapat digunakan untuk pengajaran matematika online. Youtube dapat merangsang ide-ide pendidik dan meningkatkan kreativitas dan aktivitas pendidik dalam proses belajar mengajar online. Dengan menggunakan YouTube, pembelajaran menjadi lebih menarik dan meningkatkan pemahaman konsep matematika siswa untuk pembelajaran matematika. Pendidik juga diharapkan dapat menyampaikan kepada siswa bahwa dampak negatif dari youtube adalah agar siswa tidak terpengaruh oleh hal-hal yang tidak diinginkan.
\end{abstract}

Kata Kunci: Matematika, Pemahaman Konsep, Youtube

\begin{abstract}
This research is a descriptive qualitative research with a case study approach through observation, interviews and literature study, which is located at SMP Tanjung Jakarta Barat. The population and sample in this study were 2 mathematics educators and 10 students. Data analysis used in this research is through data reduction, data presentation, and verification. Teaching mathematics using youtube media is very useful and interesting because youtube facilities are many and varied and can be chosen according to the wishes of the user. Mathematics teaching materials are also available and can be accessed by anyone, anywhere. can be used for online mathematics teaching. Youtube can stimulate educators' ideas and increase the creativity and activity of educators in the online teaching and learning process. By using YouTube, learning becomes more interesting and improves students' understanding of mathematical concepts for learning mathematics. Educators are also expected to convey to students that the negative impact of YouTube is so that students are not affected by unwanted things.
\end{abstract}

Key Word: Mathematics, Concept Understanding, Youtube

\section{PENDAHULUAN}

Di abad 21 sekarang ini kemajuan teknologi khususnya di bidang pendidikan tidak dapat kita hindari. Dengan kemajuan itu pendidik wajib untuk dapat memanfaatkan dan mengoperasikan teknologi dalam perkembangannya. Pendidik harus mampu memberikan pengajaran kepada peserta didik agar dapat menguasai berbagai mata pelajaran khususnya matematika yang penuh dengan tingkat kesulitan yang tinggi. Di era pandemi sekarang tentunya pembelajaran work from home atau pembelajaran jarak jauh sangat dianjurkan dengan catatan pembelajaran ini harus dapat menggunakan media online sebagai media pembelajaran. Perkembangan teknologi informasi juga didukung oleh internet yang sekarang ini telah menjadi hal yang sangat dibutuhkan oleh semua pihak (Anggraini, D. R., 2018). Selain itu, Pembelajaran daring sebagai tantangan tenologi digital terbukti efektif dilaksanakan pada masa WFH akibat pandemik (Arofah, K. 2015). Teknologi informasi sangat berdampak pada dunia pendidikan di Indonesia khususnya, seperti dalam hal mendapat informasi, referensi ter up to date bagi 
pendidik baik dalam hal materi maupun media pembelajaran.

Sekarang ini dunia diberikan sebuah cobaan dengan virus corona virus disease 19 (covid 19). Virus ini merupakan virus RNA strain tunggal positif yang menginfeksi saluran pernapasan pada manusia (Chandra, E., 2018). Hal ini juga pastinya berdampak pada dunia Pendidikan karena dalam hal ini kepala pemerintahan di dunia memberhentikan aktivitas dan hanya berada di dalam rumah. Pemerintah sudah melakukan langkah efektif salah satunya adalah memberhentikan proses belajar mengajar dan diganti dengan work from home. Akibatnya dalam hal pembelajaran matematika tidak bisa bertatap muka secara langsung. Dengan kondisi yang demikian tentunya pendidik harus memiliki keahlian dalam memanfaatkan media sosial untuk keberlangsungan pengajaran online. Secara umum media sosial memiliki ciri-ciri umum, yaitu: (a) Pesan yang disampaikan dan diterima tidak meliputi tiap personal tetapi meliputi banyak pengguna; (b) Pesan yang disampaikan tidak terkontrol dan bebas; (c) Pesan yang disampaikan di proses dengan cepat di bandingkan media lainnya; (d) Penerima pesan yang dapat menentukan waktu hubungan (Darmalaksana, W., Hambali, R. Y. A., Masrur, A., \& Muhlas., 2020).

Sumber daya manusia sangat penting di negara berkembang, seperti Indonesia, hal tersebut secara umum dapat diidentikkan dengan pendidikan formal yang sekarang dilaksanakan di rumah secara daring dan secara langsung dapat mempengaruhi terbentuknya sumber daya yang dapat meningkatkan kualitas bangsa. Dalam hal ketertersediaan berbagai macam sumber daya yang berkualitas, maka suatu negara akan dapat berkembang secara baik dan maksimal. Untuk memperlancar suatu proses pendidikan di Indonesia maka diperlukan wadah atau lembaga yang disebut sekolah dimana setiap peserta didik di tuntut untuk dapat membekali diri mereka dengan pengetahuan matematika yang lebih baik sehingga dapat memperoleh sebuah pengetahuan dalam rangka menembus persaingan yang ketat dan mendapatkan haknya dibidang matematika dan mereka lebih termotivasi untuk berkembang serta memahami konsep matematika dengan baik.

Dengan memahami konsep matematika, peserta didik akan dikatakan berhasil dalam menuntut ilmu pengetahuan dan juga akan dianggap sebagai sumber daya yang baik dan berkualitas. Keberhasilan dalam pemahaman konsep tersebut akan berdampak langsung terhadap kualitas pendidik. Namun disisi lain di jaman sekarang ini banyak para pendidik yang menyampaikan materi ke peserta didik dengan menyalin materi yang sudah ada, yang pada akhirnya kemampuan pemahaman konsep matematika peserta didik pun tidak ada peningkatan dari tahun ke tahun, khususnya pada mata pelajaran matematika. Pemahaman konsep itu harus diberikan ke peserta didik sejak kecil yaitu pada saat anak yang bersangkutan duduk di sekolah dasar. Peserta didik dituntut mengerti mengenai pengertian, definisi, cara pemecahan sebuah masalah maupun pengoperasian matematika secara baik dan benar (Dewi, E. R., 2018). Hal ini pun terjadi pada pendidik SMP Tanjung Jakarta Barat, karena pendidik matematika secara turun temurun sehingga kurang media pembelajaran untuk proses penyampaian materi ajar ke peserta didik. Penyampaian pendidik matematikapun seadanya, memberikan catatan dan latihan secara terus menerus tanpa menjelaskan, tidak melihat apakah sesuai materi dan kondisi untuk peningkatan pemahaman konsep peserta didik.

Era globalisasi ini telah membawa sebuah perkembangan yang pesat dalam teknologi informasi dan komunikasi. Menurut Herawati, O. D. P., Siroj, R., \& Basir, D. (2013) terdapat beberapa faktor yang menentukan keberhasilan pembelajaran, salah satu diantaranya adalah penggunaan media pembelajaran, teknologi serta tenaga pengajar. Tenaga pengajar merupakan fasilitator utama dalam proses belajar mengajar yang berperan dalam pencapaian dari tujuan pembelajaran. Pemilihan Strategi dalam pembelajaran yang cukup menarik dan 
konvensional serta media untuk pengajaran yang menarik dan tepat akan dapat membantu meningkatkan pemahaman konsep matematika peserta didik terhadap materi pembelajaran secara efisien dan efektif.

Teknik pembelajaran ekspositori dan konvensional cenderung membuat proses pembelajaran matematika sangat membosankan dan tidak menarik karena suasana proses pembelajaran di kelas hanya berpatokan kepada pendidik sebagai sumber belajar dan cenderung peserta didik merasa kesulitan untuk fokus dan memahami konsep pembelajaran matematika yang diajarkan. Kebanyakan mencatat dan tidak pernah menerangkan materi ajar berakibat proses pembelajaran menjadi tidak kondusif, menarik, dan inovatif bagi peserta didik. Metode konvensional cenderung menjadikan siswa tidak aktif dalam belajar dan tidak inovatif (Iwantara, I., Sadia, M., \& Suma, M., 2014). Melihat berbagai permasalahan pembelajaran di lapangan, maka siswa tidak terbiasa menggunakan daya nalarnya, tetapi hanya terpaku pada buku sumber serta terasa ada jurang pemisah antara guru dan siswa (M. Yusuf Efendi., 2014). Sehingga dalam dunia pendidikan dibutuhkan sebuah media pembelajaran agar apa yang diharapkan dapat tercapai dengan baik. Sekolah harus mampu menyesuaikan dengan berbagai macam perkembangan ilmu dan teknologi, salah satunya menjadikannya dalam proses pembelajaran yang menarik dan menyenangkan. Pendidik memiliki peran yang cukup sentral dalam mengembangkan inovasi, dan gagasan untuk pemanfaatan teknologi dalam pembelajaran demi meningkatkan efektifitas dan pemahaman konsep matematika yang cukup sulit.

Di Era Pandemi ini sudah saatnya sekarang ini, pendidik tidak lagi menggunakan teknik pengajaran konvensional dalam proses pembelajaran online. Kebanyakan pendidik hanya memberikan tugas dan latihan dengan media Whattsapp dan peserta didik disuruh mengerjakan semampunya saja. Pergeseran tentang paradigma pendidikan dalam pembelajaran online seharusnya mengikuti perkembangan teknologi modern. Salah satunya adalah dengan memanfaatkan perkembangan teknologi melalui youtube sebagai media pembelajaran. Dengan youtube, pendidik dapat menampilkan video pembelajaran yang interaktif, inovatif dan menarik.

YouTube adalah situs website media untuk sharing video online terbesar dan paling populer di internet. Saat ini pengguna youtube tersebar di seluruh dunia terdapat dari berbagai kalangan usia, dari tingkat anak-anak sampai dewasa. Pengguna youtube dapat memanfaatkan konten mengupload video, menonton video, search video, kolom komentar untuk tanya jawab tentang video dan sekaligus berbagi klip video secara gratis tanpa berbayar. Setiap hari terdapat jutaan orang yang mengakses youtube sehingga tidak salah jika Youtube sangat berpotensi untuk dimanfaatkan sebagai media pembelajaran matematika interaktif. Media pembelajaran penting dan berguna dalam mempelajari dengan media video dan tayangan yang ada pada media social salah satunya adalah YouTube (Rahmawan, D., Mahameruaji, J. N., \& Janitra, P. A., 2018).

Tujuan dalam pemanfaatan media youtube sebagai salah satu media dalam proses pembelajaran adalah menciptakan suasana pembelajaran yang tidak monoton, menyenangkan, menarik, dan interaktif. Video di youtube pemanfaatannya untuk pembelajaran yang interaktif di kelas, baik buat peserta didik maupun pendidik melalui presentasi secara langsung ataupun offline. Pemanfaatan media youtube sebagai media pembelajaran dapat digunakan setiap saat tanpa dibatasi olah ruang dan waktu dengan syarat komputer atau media presentasi terhubung dengan internet. Penggunaan media YouTube oleh semual kalangan karena selain tertarik pada platformnya yang memadukan teks, audio dan video, media youtube juga menawarkan komunikasi dua arah (Sianipar, A. P., 2013).

Youtube memiliki banyak keunggulan jika digunakan sebagai media pembelajaran khususnya matematika yang potensial antara

914 | Analisis Pemanfaatan Media Pembelajaran Youtube dalam Meningkatkan Pemahaman Konsep Matematika Peserta Didik 
lain youtube adalah situs yang terpoluper di internet saat ini yang mampu memberikan edit value terhadap dunia pendidikan. Youtube telah menjadi fenomena mendunia yang merupakan situs video sharing yang dapat berfungsi sebagai sarana untuk share video secara online yang penggunanya paling banyak di Indonesia adalah remaja dewasa dan pemuda sehingga berpotensi untuk pembentukan bakat diri seseorang (Simbolon, N., 2014). Praktis yaitu youtube sangat mudah digunakan dan dapat diikuti oleh seluruh kalangan termasuk peserta didik dan pendidik. Informatif yaitu youtube memberikan informasi yang menarik tentang perkembangan ilmu pendidikan, teknologi, kebudayaan. Interaktif yaitu youtube memfasilitasi pendidik untuk berdiskusi atau melakukan tanya jawab bahkan mereview sebuah video pembelajaran. Sheareable yaitu youtube memiliki fasilitas link HTML, Embed kode video pembelajaran yang dapat di sheare di jejaring sosial pribadi masingmasing seperti facebook, twitter dan juga website; Ekonomis yaitu youtube gratis untuk semua kalangan [12].

Untuk memanfaatkan youtube sebagai media pembelajaran matematika, pendidik harus mengetahui secara spesifik tentang Bagaimana membuat account di youtube; Bagaimana cara dalam hal mengupload video pembelajaran matematika di youtube sehingga dapat diakses oleh seluruh peserta didik atau semua orang; Bagaimana search atau mencari video pembelajaran matematika di youtube untuk menambah pengetahuan peserta didik maupun pendidik; Bagaimana mendownload video pembelajaran di youtube, baik itu tanpa software maupun dengan menggunakan software; Bagaimana memutar video pembelajaran matematika dari youtube, baik secara online maupun offline setelah video tersebut didownload; Bagaimana menggunakan video pembelajaran matematika agar terintegrasi dengan powerpoint untuk digunakan presentasi online seperti sekarang ini. Melihat kondisi ini, maka penulis memaparkan Pemanfaatan Media Pembelajaran Youtube Dalam Meningkatkan efektifitas dan pemahaman konsep matematika peserta didik SMP Tanjung di Jakarta Barat.

\section{METODE PENELITIAN}

Penelitian ini merupakan penelitian kualitatif deskriptif dengan pendekatan studi kasus melalui observasi, wawancara dan studi dokumen, yang bertempat SMP Tanjung Jakarta Barat. Sekolah tersebut dijadikan tempat penelitian karena merupakan salah satu sekolah swasta yang dibangun untuk memfasilitasi dunia pendidikan di daerah Grogol. Populasi dan sampel dalam Penelitian ini sebanyak 2 orang Pendidik matematika SMP Tanjung dan 10 orang peserta didik SMP Tanjung. Analisis data yang digunakan dalam penelitian ini adalah melalui reduksi data, penyajian data, dan verifikasi. Namun ketiga tahapan tersebut berlangsung secara simultan.

\section{HASIL DAN PEMBAHASAN}

Pemanfaatan youtube sebagai salah satu media pembelajaran mata pelajaran matematika sesungguhnya sangat penting digunakan karena melalui youtube peserta didik dapat melaksanakan belajar atau mendengar langsung penjelasan dari pendidik. Dengan melihat secara visual tentu akan melahirkan kepercayaan diri dan minat yang kuat bahwa penjelasan konsep matematika yang dilihat dan dengar sudah tepat dan dipahami, sehingga pada saat diberikan tugas dan latihan peserta didik tersebut akan dapat mengerjakan soal matematik yang diberikan walaupun terjadi perubahan dari redaksi soal yang telah diberikan.

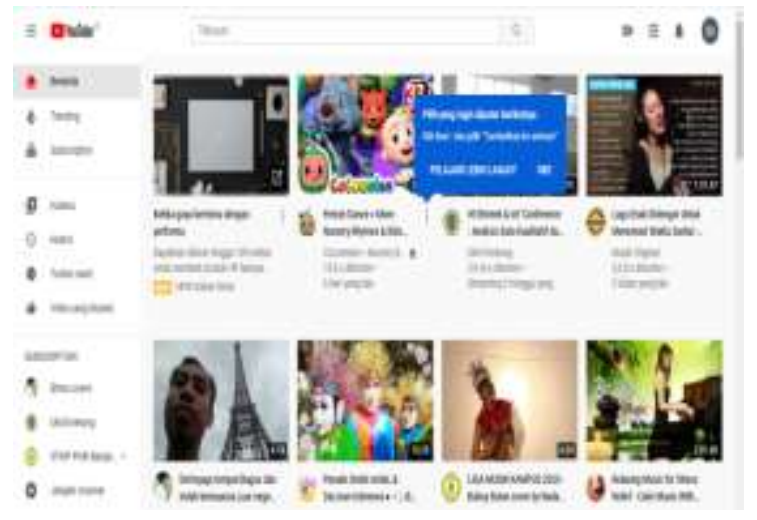

Gambar 1. Tampilan Awal Youtube

Pemanfaatan YouTube sebagai media pembelajaran membantu ketersampaian pesan. Menurut Sri Wuryastuti. (2018), YouTube mempunyai salah satu layanan dalam berbagi video yang tersedia di media

915 | Analisis Pemanfaatan Media Pembelajaran Youtube dalam Meningkatkan Pemahaman Konsep Matematika Peserta Didik 
internet paling popular saat ini. YouTube sebuah situs web video sharing yang dapat memungkinkan pengguna mencari video, menggunggah, menonton, tanya jawab dan berbagi klip video secara gratis. Video tersebut adalah film, klip, TV, serta video buatan pengguna. YouTube menjadi salah satu situs online video provider yang paling dominan di seluruh dunia dan tidak akan membatasi durasi untuk mengunggah video. Keunggulan lain, YouTube adalah menawarkan layanan gratis khususnya untuk menikmati dan mengakses video yang masuk dalam sistemnya. Untuk mengakses video pengguna tidak perlu memiliki akun bebayar sejumlah uang dalam skala waktu tertentu. Pengguna dapat mengakses video-video tersebut secara gratis. Pengguna YouTube dapat mengunduh beberapa video dan setelah berhasil terunduh, video dapat disimpan di gadget masing-masing untuk dinikmati kapan tanpa menggunakan sambungan internet. YouTube digunakan sebagai media pembelajaran karena merupakan salah satu media yang dekat dengan kehidupan siswa sehari-hari.

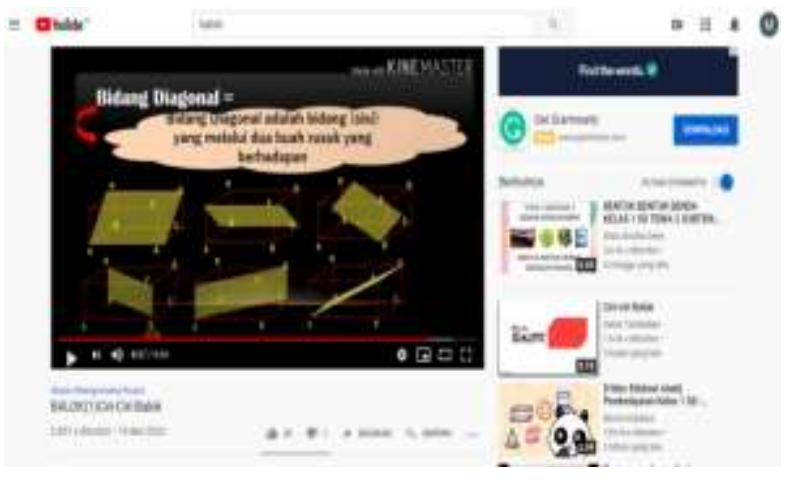

Gambar2. Contoh Video Pembelajaran di YouTube

Penelitian ini dilakukan dengan cara memberikan sosialisasi kepada pendidik tentang manfaat dari penggunaan media pembelajaran Youtube bagi dunia pendidikan, salah satunya pembelajaran matematika. Langkah selanjutnya adalah memperkenalkan berbagai metode yang cukup sederhana untuk mendownload bahan-bahan materi matemtika. Cara pertama adalah dengan memperkenalkan www.savefrom.net dan yang kedua adalah mendownload program. Pada sesi ini peserta tidak dibebani dengan materi dan teori yang cukup rumit. Sesi berikutnya adalah masuk di praktek, yakni pennjelasan dan pendidik langsung mencoba secara terus menerus bagaimana mendownload program matematika yang diinginkan pendidik. Peserta juga diberikan program downloader yang sudah dimiliki oleh peneliti, sehingga memudahkan peserta untuk menggunakan aplikasi ini.

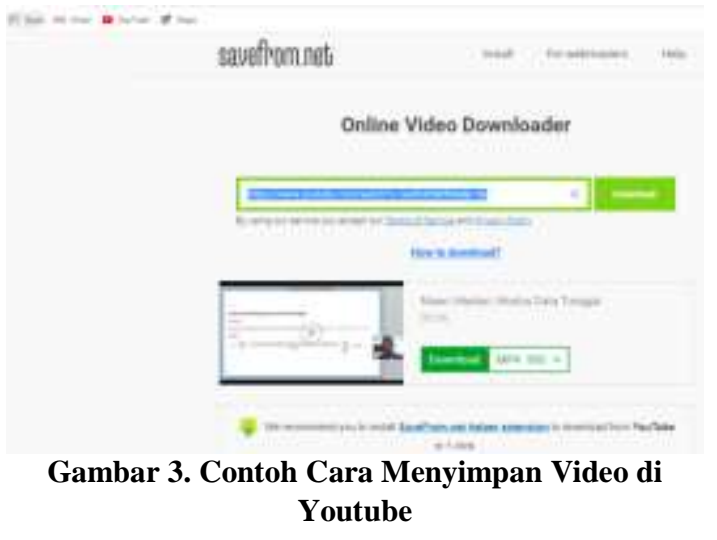

Pada awalnya, pemahaman Pendidik terhadap fasilitas youtube belum sepenuhnya maksimal yakni mereka belum memahami bahwa youtube itu menyediakan banyak informasi yang sangat berguna bagi media pengajaran matematika. Hal ini disebabkan oleh faktor antara lain pendidik lebih mengalihkan fokus kepada kurikulum yang ada dan tidak sepenuhnya mau untuk berinovasi dalam metode pengajaran matematika. Faktor kedua adalah masih minimnya fasilitas seperti wifi, infokus dan listik yang sering padam, setelah pendidik diberikan beberapa pemahaman dan dicoba diterapkan ternyata media Pembelajaran youtube merupakan salah satu media alternatif yang bisa digunakan oleh pendidik sebagai media dalam menyampaikan materi matematika pada saat proses pembelajaran. Hal tersebut sesuai dengan yang diungkapkan oleh (Snelson, C., 2011), menonton youtube itu lebih baik dibandingkan dengan hanya sekedar membaca atau mendengarkan audio saja.

Selain itu, youtube juga bisa dimanfaatkan untuk semua pokok pembahasan, modelmodel pembelajaran, dan setiap ranah: kognitif, afektif, dan psikomotorik. Pada ranah kognitif, peserta didik dapat melakukan

916 | Analisis Pemanfaatan Media Pembelajaran Youtube dalam Meningkatkan Pemahaman Konsep Matematika Peserta Didik 
pemahaman konsep menentukan rusuk kubus atau balok dengan warna, karena unsur tersebut mampu membuat gambar berasa lebih menarik. Selain itu dengan melihat youtube, setelah atau sebelum membaca, dapat memperkuat pemahaman konsep peserta didik terhadap matematika. Pada ranah afektif, youtube dapat memperkuat peserta didik dalam merasakan unsur emosi dan penyikapan dari pembelajaran yang matematika kreatif. Kreator konten di dalam YouTube yang menjalankan fungsi media edukasi bagi peserta didik mengemas kontennya dengan menggunakan animasi, bahasa, dan penjelasan yang mudah, serta beberapa akun layanan pendidikan seperti Quipper, Zenius, dan Ruang Pendidik yang memiliki kanal berisikan bahan pembelajaran elektronik, tutorial dan tips pembelajaran (Wirga, E. W., 2016).

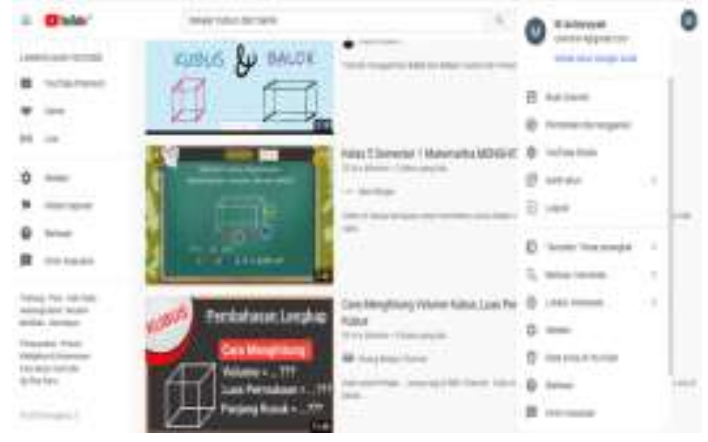

Gambar 4. Contoh Pencarian Video Pembelajaran Matematika

Pada ranah psikomotorik, youtube memiliki keunggulan dalam memperlihatkan bagaimana sesuatu bekerja, video pembelajaran yang merekam kegiatan motorik dapat memberikan banyak kesempatan pada peserta didik untuk mengamati dan mengevaluasi kembali konsep matematika yang telah diajarkan tersebut. Sebagai bahan ajar online, youtube sangat kaya akan informasi yang digunakan dalam suatu proses pembelajaran karena bisa sampai ke peserta didik secara langsung. Selain itu, youtube menambah dimensi baru dalam pembelajaran matematika, peserta didik tidak hanya melihat gambar dari bahan ajar cetak dan suara dari program audio, tetapi di dalam youtube, peserta didik bisa memperoleh semuanya, yaitu gambar bergerak beserta suara yang menyertainya. Penerapan media youtube akan dapat menghadirkan sesuatu yang dapat dilihat dan didengar sehingga dapat memotivasi peserta didik untuk belajar dan memberikan pengalaman belajar kepada peserta didik (Yuliana., 2020).

Youtube menyediakan berbagai informasi yang penting berupa video yang bisa di akses dan dilihat oleh siapa saja. Fasilitas ini sangat memungkinkan digunakan untuk kepentigan pengajaran dan pembelajaran di sekokah seperti pengenalan bangun ruang contohnya kubus, balok, tabung, bola, limas, prisma dan banyak lagi fasilitas yang lainnya. Meskipun fasilitas yang ada sangatlah banyak namun tidak semua orang mau memanfaatkannya untuk dunia pendidikan.

Pemanfaatan youtube dapat merangsang efektifitas, minat dan motivasi pendidik. Selain itu melalui youtube, kemampuan pemahaman konsep matematika bisa maksimal, penyusunan bahan ajar, pemilihan materi yang sesuai, cara penyampaian pendidik mengalami kemajuan, yang awalnya hanya mennyalin dan menjiplak dari youtube menjadi sebuah materi, bahan baru yang penuh ide dengan gaya pendidik masingmasing. Youtube pun secara tidak langsung meningkatkan efektifitas belajar diantara mereka, dalam hal pencarian ide dan materi matematika

\section{SIMPULAN DAN SARAN}

Pengajaran matematika dengan menggunakan media youtube sangat menyenangkan karena fasilitas youtube banyak dan variatif serta bisa dipilih sesuai dengan keinginan penggunanya. Bahan pengajaran matematika juga tersedia dan bisa diakses oleh siapa saja dan dimana saja. sehingga bisa digunakan untuk pengajaran online mata pelajaran matematika. Youtube dapat merangsang ide pendidik dan meningkatkan kreatifitas dan aktivitas pendidik dalam proses belajar mengajar online. Kegiatan ini dapat diteruskan di sekolah-sekolah lain karena memberikan manfaat tidak hanya kepada pendidik tetapi juga kepada peserta didik. Dengan menggunakan youtube, pembelajaran menjadi lebih menarik dan meningkatkan pemahaman konsep matematika peserta didik untuk belajar matematika. Pendidik juga diharapkan 
menyampaikan kepada peserta didik bahwa dampak negative dari youtube, agar peserta didik tidak terpengaruh hal yang tidak diinginkan.

Berdasarkan hasil penelitian ini, dapat disarankan beberapa hal kepada: 1) Guru diharapkan lebih kreatif dalam memilih media pembelajaran sehingga dapat meningkatkan pemahaman konsep matematika siswa. 2) Kepala sekolah diharapkan lebih memberikan kesempatan kepada guru untuk mengembangkan kompetensi yang dimilikinya. 3) Peneliti sejenis kiranya dapat menggunakan hasil penelitian ini sebagai bahan referensi untuk mengembangkan media pembelajaran sehingga mampu mengatasi permasalahan dalam pembelajaran matematika

\section{UCAPAN TERIMAKASIH}

Ucapan Terima Kasih Kami ucapkan kepada Kepala sekolah SMP Tanjung Jakarta Barat beserta segenap guru yang telah membantu dalam penelitian ini.

\section{DAFTAR PUSTAKA}

Anggraini, D. R. (2018). Pemanfaatan Youtube Sebagai Media Pembelajaran Dalam Meningkatkan Kreatifitas Guru Bahasa Inggris Mts Al-Insan. Universitas Muhammadiyah Tanggerang.

Arofah, K. (2015). Youtube Sebagai Media Klarifikasi dan Pernyataan Tokoh Politik. Jurnal Ilmu Komunikasi.

Chandra, E. (2018). Youtube, Citra Media Informasi Interaktif Atau Media Penyampaian Aspirasi Pribadi. Jurnal Muara Ilmu Sosial, Humaniora, Dan Seni.

https://doi.org/10.24912/jmishumsen.v1 i2.1035

Darmalaksana, W., Hambali, R. Y. A., Masrur, A., \& Muhlas. (2020). Analisis Pembelajaran Online Masa WFH Pandemic Covid-19 sebagai Tantangan Pemimpin Digital Abad 21. Karya Tulis Ilmiah (KTI) Masa Work From Home (WFH) Covid-19 UIN Sunan Gunung Djati Bandung Tahun 2020.

Dewi, E. R. (2018). Metode Pembelajaran Modern Dan Konvensional Pada Sekolah Menengah Atas. PEMBELAJAR: Jurnal Ilmu
Pendidikan, Keguruan, Dan

Pembelajaran.

https://doi.org/10.26858/pembelajar.v2i 1.5442

Herawati, O. D. P., Siroj, R., \& Basir, D. (2013). Pengaruh Pembelajaran Problem Posing Terhadap Kemampuan Pemahaman Konsep Matematika Siswa Kelas Xi Ipa Sma Negeri 6 Palembang. Jurnal Pendidikan Matematika. https://doi.org/10.22342/jpm.4.1.312.

Iwantara, I., Sadia, M., \& Suma, M. (2014). Pengaruh Penggunaan Media Video Youtube Dalam Pembelajaran Ipa Terhadap Motivasi Belajar Dan Pemahaman Konsep Siswa. Jurnal Pendidikan Dan Pembelajaran IPA Indonesia.

M. Yusuf Efendi. (2014). Pengaruh Perkembangan Teknologi Informasi. In 9 januari 2014.

Rahmawan, D., Mahameruaji, J. N., \& Janitra, P. A. (2018). Potensi Youtube Sebagai Media Edukasi Bagi Anak Muda. Edulib. https://doi.org/10.17509/edulib.v8i1.11 267

Sianipar, A. P. (2013). Pemanfaatan youtube di kalangan mahasiswa. Jurnal Ilmu Komunikasi FLOW.

Simbolon, N. (2014). Faktor Faktor Yang Mempengaruhi Minat Belajar Peserta Didik. Elementary School Journal Pgsd Fip Unimed.

Snelson, C. (2011). YouTube across the Disciplines : A Review of the Literature. Journal of Online Learning and Teaching.

Sri Wuryastuti. (2018). Inovasi Pembelajaran IPA di Sekolah Dasar. Jurnal Pendidikan Dasar.

Wirga, E. W. (2016). Analisis Konten Pada Media Sosial Youtube untuk Mendukung Strategi Kampanye Politik. Jurnal Ilmiah Informatika Dan Komputer.

Yuliana. (2020). Corona Virus Diseases. Corona Virus Diseases. 